\title{
Becoming a Gang Member: Youth Life and Gang Youth
}

\author{
Sven Mørch, Helle Andersen \\ Copenhagen University, Copenhagen, Denmark
}

\begin{abstract}
The purpose of this paper is to develop a framework for understanding the growth in youth gangs and gang behaviour. The paper builds on a youth theory perspective and describes how the social conditions work with or are against the young individual in such a way that gangs seem to be an option or an answer for some young people when faced with today’s youth life situation. In this study, it focuses on the development of social vs. societal gangs, and on the late modern challenges of individualised social responsibility and the use of social relations in managing individualisation problems.
\end{abstract}

Keywords: youth research, youth gangs, gang behaviour, individualisation

In Denmark and other Scandinavian countries, problem youth has indeed acquired an entirely new topicality with the latest development of gang-related assault and shooting dramas, and even though gangs are not just a youth phenomenon, a key question is whether there may be a correlation between the late-modern youth life and the development of gang behaviour. Gang behaviour has mostly been seen as individual behaviour explained in reference to group theory, racial studies, marginalisation theory, or crime or antisocial behaviour analysis. Also, contemporary writings of gang behaviour are still focused not only on gang activities as social problems, but also more directly on youth gangs (Klein, 2001; Holligan \& Deuchar, 2009).

The purpose of this paper is to further develop a framework for understanding the growth in youth gangs and gang behaviour which does not individualise or psychologise the understanding of the individual gang member. Therefore, the analysis of gang recruitment and gang behaviour will focus on youth life and draw on a youth research perspective.

Youth research is of course not unambiguous, but follows more different lines. In American research, youth is mostly conceptualised as "adolescence" and understood as some sort of biological and psychological developmental phase which causes identity problems among young people. In European research, youth has mostly been understood as a social or even societal time of transition between childhood and adulthood. As a time of "youthhood", this youth research approach is developed both as a critic of American psychological adolescence research and in accordance with the European post-war interest in understanding problem youth (Mørch, 2010). European youth research, therefore, answers the challenge of transforming young people from being problem youth and passive followers to becoming active participants in the new democratic and changing societies (Mørch, 2003).

\section{Youth Life Development and Social Integration}

One of the most striking aspects of youth social integration challenge today is that social control and 
regulation are changing rapidly. Today's social integration calls for active individuals and individual skills and initiatives, and a person can in a completely new sense choose her/his own life and her/his relation to society. But this also underlines that young people, such as kids from "social problem families" and "ethnic minority youth" who are in some way marginalised in the overall social integrative process may in fact develop an "disintegrative integration praxis", i.e., social functioning, but not in recognised forms.

Historically, youth life is formed as a time of "individualisation in biography" (Mørch, 1985, 2010; Gillis, 1981; Stafseng, 1996). The focus at the process of "individualisation in biography” points to important aspects of youth development in a changing world: Individualisation demands are constantly changing, and this also changes the individual biography.

A very important change in individualisation follows from a change from modern to late-modern consumer or risk society (Baran \& Sweezy, 1968; Galbraith, 1967; Bauman, 1997; Beck, 1997). The other important change is in the biography, which makes people "young” earlier and earlier, but also delays the possibilities of becoming an adult (Frønæs \& Brusdal, 2000; Côté, 2000; Bechmann, 2004).

Today the institutional deinstitutionalisation' process typical of post- or late- modern society has made individualisation and identity formation a lifelong challenge. In opposition to this development, the former Bourgeois society was an institutional society, predominantly organised by institutions which formed the lives of children and young people through rules and prohibitions. Family, school, and other institutions organised every stage of life from childhood to adulthood, but with the development of late-modern society, many routines in the institutions did not seem appropriate to the creation of a kind of individualisation suitable for this new era. Therefore, there had to be a detachment or liberation from institutional pressures (Ziehe \& Stubenrauch, 1982; Mørch, 2010).

The societal deinstitutionalisation led to a new individualisation process and a growing and necessary empowerment of children and young people. The deinstitutionalised society created and demanded the development of self-determination and self-responsibility: The individual would now be personally responsible for the project of finding his/her way in the world (Mørch, 2010). The individualisation process, therefore, more and more has made the "person" and the individual "identity" the important late-modern construct both in public and in individual understanding.

The challenges for young people regarding their future plans and the growing complexities in late-modern society imbue the self-determination with an increasing perplexity. Self-determination and self-responsibility open the door not only to free and exciting opportunities, but also to multiple problems for both youth and society, not least when young people have to develop a sociality that unites personal self-responsibility with social responsibility. This task seems difficult to be defined and dealt with, because self-responsibility is often merely seen as a desire to decide matters oneself, which does not necessarily promote social integration and a qualified self-determination in a societal context. In many ways, young people are forced into situations that involve personal decisions on matters which are often impossible to relate to. Deinstitutionalisation thus also points to new forms of "individual institutionalisation" or "structuration", as Giddens called it (Giddens, 1987; Mørch, 2010). The requirement for individual structuring skills calls for social support and especially peer friendships to help solve the challenges. Friends thus become a key aspect of individualised youth life.

Many of the problems which arise in youth life are caused by the societal challenges of deinstitutionalisation. And young people who do not take up the offers of education in its broadest sense and thus the inherent possibilities of individualisation could face a "relative de-individualisation", i.e., a situation 
where they do not develop the necessary individual capabilities to engage in and benefit from the opportunities offered by society. This relative deindividualisation may also contribute to the types of behaviour chosen, including those relating to conflict resolution which may appear immature and crude, contrasting with the ways people usually act on an everyday basis.

\section{How Young People Choose Their Own Lives}

The deinstitutionalisation perspective indicated that young people's lives have increasingly become their own and can be regarded as freer than before. Young people may do things just because they can. Therefore, increased attention is certainly being given to young people's own aspirations and perspectives. But this does not mean that their lives have become entirely their own. Their lives are in many respects still regulated and "blocked". There are many who seek to control and influence young people. The families, the schools and educational systems, political campaigns, and especially the media assert influence on young people's lives.

The most interesting aspect of this trend does not seem to be that young people are being shaped, or where this shaping originates, but how it happens. Today's youth are no longer obliged to do things; they are influenced to do things. The decisions belong to the young people themselves, but the basis for the decisions and the circumstances surrounding them are now much more controlled by outsiders and more dominant in everyday life.

Young people today are "individual" and "social" in new ways, and they can more easily break with their social conditioning and establish their own lives than before. They do so even to the extent that youth are today often seen as typified by self-presentation in social relations. There are therefore good reasons for the common perception of young people as having a deep involvement in finding and shaping their identity as a distinctive trademark in social relational contexts. And this is, by no means, only about clothes, makeup, piercing, and other commercially based possibilities, but also in a broader sense of their lifestyle presentation. Young people are more or less defined through their lifestyle, and lifestyle is their way of positioning themselves as persons in youth life. Lifestyle signals one's distinctiveness and identity. Young people find inspiration for these lifestyle choices in various aspects of society. The media in particular often present success as linked to lifestyles which demonstrate a highly private and self-centred approach to humanity (Andersen \& Mørch, 2005).

These complicated and popular approaches indicate entirely new challenges in our understanding of youth life and individual young people (Arnett, 2004; Mørch, 1995; Côté, 2000). Young people should not only be seen as individuals who are influenced by social and societal life. Young people are formed or constructed as individuals in their lifestyle activities and therefore should be understood in a life course or trajectory perspective (Mørch, 2003; 2010).

The trajectory concept captures a particular aspect of late-modern individualisation. When we want to understand why people do something specific, we often have the idea that there are particular individual reasons for their action. They may have specific motives, needs, prejudices, etc., but this need not be the case. A central aspect of our present-day society is that we may do things just because we can, because we receive support for our decisions, or because the actions fit into our overall trajectory. The trajectory concept indicates that actions are contextual and held together by a superior development logic of spaces of possibilities, such as school life, group belonging, Internet activities, media offerings, etc., which all shape our conditions for actions. Actions are enabled in a trajectory perspective and we can create our own life course and ourselves within this logic. One can even imagine that what we can do shapes the needs and motives we give as reasons for our 
actions (Giddens, 1987).

The trajectory requirement may also show the problems of late-modern youth life. It is not always easy for young people to make connections between individual and societal trajectories. It is particularly obvious that young people who do not experience success in a societal trajectory, especially in education, may find it difficult to connect their own lives with societal opportunities. Many of them will thus be left to create their own private trajectory or to find other "societal" trajectories or lifestyles which may support distinctiveness and identity.

\section{The Content of Youth Life}

In the individualised trajectory development, young people become increasingly dependent on social references and social support. Although parents want to help their children, the worlds of parents and youth are so different that it can be both difficult for parents to lend support and irrelevant for the young people to take up the offers of support. So the need for social support and advice gives the peer group its entirely new significance. The peers who are in the same situation as their friends are seen as the local and contextual experts.

However, friends often have the same kind of challenges, circumstances, and future prospects as the young person himself/herself. So, when young people become dependent on friends support, friends helps reproducing typical attitudes and practices bound by gender, social class, and ethnicity. There thus seems to be a contradiction inherent in maximum individualisation; the more individualised young people become, the more individual lives are increasingly directed towards and depended on the group. Young people need the social support which also reproduces their social, gender, and ethnic position.

The trajectory perspective reveals these problems. Young people's individual trajectories can evolve in a manner where they do not associate themselves (even critically) with society, but with self-presentation and personal group belonging. This is particularly true of young people with a weak family, educational, cultural, and socio-economical background. They may seek support in the nearest group or gang relations, which both underpin the legitimacy of their actions and also lay down rules for the direction of self-responsibility.

\section{School and Education}

The educational process is the most important social trajectory of young people and they must find ways of connecting their own and the social trajectory.

There are however two different logics in the educational process: diversity and differentiation. Diversity suggests that people may have and follow different trajectories both as a foundation and as a developmental perspective. It accepts that people are different and also deal with their lives in different ways. Therefore, their trajectories should be supported and they should learn according to their abilities. Differentiation, however, is less clear. Differentiated teaching in school is focusing on the same goal for all students. Therefore, it can easily lead to inequality and differences in young people's empowerment if the individual is not able to reach the goal. Therefore, differentiated teaching may create school losers.

Today educational system with its common learning goals and PISA evaluation ${ }^{1}$ perspectives may ignore young people’s diversity and life perspectives. It may create schools that differentiate and exclude some young

\footnotetext{
${ }^{1}$ The EU Programme for International Student Assessment. An evaluation system used to measure and compare learning results in EU countries.
} 
people from school learning opportunities. Schools perhaps even become partially responsible for the marginalisation of young people with a disadvantaged background who encounter a discriminatory learning environment and meagre perspectives of educational success.

When considering the great importance of education in the individualisation process, it is clear that an educational process that differentiates pupils is helping to push young people out into marginalisation. And when the press and TV constantly tell that young people without good education are doomed to become losers in society, it is not just a question of objective information. For many young people, it is understood as a direct personal attack, which reinforces their needs to find other forms of success in life.

\section{Societal Conditions}

If societal trajectories do not allow young people to design their own trajectory in societal terms, the social reproduction processes become highly significant. The experience of social exclusion leads naturally to a rejection of society.

Opposition to society clearly does not mean non-societal participation, which would seem almost impossible. But one of the strongest social principles appears to be that social inequality which encounters discriminatory actions, will lead to personal and social marginalisation (Furlong \& Cartmel, 1997).

While the societal foundation sets conditions for everyone, it also reveals contradictions and inequalities. One aspect is the competition to shine in the educational system. All actions for young people point to education as the path to personal success. But often, it is precisely schools and education that contribute to the creation of differences. Also, the increasing use of sport metaphors in education causes problems. Every time you praise a winner you create a loser, and clearly many aspects of school life give children a feeling of being losers. Differences are also shaped in the public sphere in everyday life and in the media. The media bombards young people with consumer perspectives that designate differentiated trajectories for gender, and forms of social action which create specific cultural and ethnic images of society and not least inclusion requirements for young people's social lives. Thus, cultural, gender, and media portrayals create a horizon of meaning for young people on which basis they seek to understand their lives. Here, inequality is often linked to qualities very different from learning and individualisation, namely, purely individual characteristics, e.g., related to appearance. Media images of success give the impression that anyone can become visible and get a chance to step into the limelight, but at the same time, they reveal that this is not possible. Not everyone can become a star in a programme like $X$ Factor. Perhaps the most important lesson in the media is that you can lose, and then it is "your own fault". Although the media creates entertainment out of inequality, the experience of inclusion and exclusion may have a strong bearing on young people's everyday lives and their ability to form a forward-looking trajectory.

If one were to point to a single challenge facing young people today, it is connected to the differentiation and inclusion demands they experience. The development of self-responsibility is not only an opportunity but also a requirement. Young people must be able to manage their lives themselves, and there is no doubt that this requirement is clearly spelled out for young people. "Talents" and the highly educated are "in", while many others are judged to be "out".

\section{Young People in Difficulties}

In an overall perspective, it is clear that young people's demanding and complex lives call for them to 
develop qualified self-determination. This process in fact succeeds amazingly well. Most young people are able to use this phase of their lives as an opportunity to ensure social integration. However, there are also young people who do not succeed. Not because they do not want to be successful in life, but because they cannot easily find out what could be success in their case, and how to reach it.

Although only a small percentage of a young generation directly develop "non-social" behaviour or decidedly "have difficulties", it is important to note that many young people are "in difficulties". Young people are trapped in a societal and socially created youth life, which can lead to the establishment of a problem of self-centredness that does not promote the development of broader social responsibility. And in this situation, young people who think society to be an obstacle in their lives may choose psychological answers as anorexia and cutting or social answers as gang life as an attractive option.

\section{“Social Gangs" and "Societal Gangs”}

The broad perspectives on late-modern youth challenges point to the special difficulties, which are influencing the increase in youth gang behaviour. Gang life is often seen as deviant group behaviour which is formed differently according to historical and social conditions and as answers to changing challenges of managing life in society (Hobsbawn, 1973).

Instead of trying to understand youth gangs as dubious and criminal youth groups, it might be an idea to choose a much simpler and pragmatic perspective. Gangs may be seen as social networks that provide space and support for the individual, but are also contexts for common activities that are often directed against the outside world. This broad description follows both practical understanding and a line in sociological theory, which pointed out that gangs developed collective behaviour, traditions, "esprit de corps", and a territorial attachment (Thrasher, 1927).

If we look at the specific (youth) gangs currently in the public eye, not only because of their visibility in the city, but also because of their particular kinds of organisation and forms of violent behaviour, we can set up a working hypothesis that there may be either "social gangs" or "societal gangs". On the one hand, many youth gangs are social to the extent that their activities consist almost in ensuring mutual support in everyday life and in maintaining social networks, i.e., guaranteeing the socially organised individual and relational life of the members. On the other hand, a societal gang refers to a kind of network of people which not only makes the members social actors, but also societal actors, i.e., participants in the broader societal life. The distinction between social and societal gang is blurred but still significant, since social gangs may have a tendency to change and lose their fascination when the young people move on into adult life, while a societal gang in itself creates a coveted adult life.

At a more general level, societal gangs may be seen as other societal organisations and business networks. Organisations, such as HA (Hells Angels), the Danish supporter groups “AK81”, and ethnic minority group "Black Cobra", are not least in their own self-understanding, forms of business enterprises or organisations involved in business.

This should be seen in conjunction with the fact that when it comes to economical interests the boundary between legality and illegality is not as sharp as many wish to portray in public. There are therefore many reasons why societal gangs are not necessarily perceived as particularly criminal by their young members. The gangs just operate in specific business areas, such as control of the drug market, the organisation of prostitution and money lending, which many young people do not necessarily consider to be different from other societal 
business activities. As such, for many young people, the gang environment represents a possible adult world in line with others. And when there are violent gang conflicts, it is merely because the conflicts of interest between the gangs do not have a clear societal arena, but must be played out directly in the gang business environment as we also know it from American gang wars. Much therefore suggests that the significance of societal gangs lies in the fact that they are both social gangs and hat they offer a young person work and future prospects, if he/she is lucky enough to get accepted in a societal gang.

\section{Joining a Gang}

We can now ask the question of the more specific logic of joining a societal gang. In simple terms, it can be stated that young people's actions should be seen as part of their strategy to manage their lives and become successful in life. Becoming a gang member should be understood as a societal "top performance" for some young people who have had educational problems and who are caught in social networks (Brückner, 1972). Peer friendship groups or gangs are attractive networks and they offer solutions to many problems. Importantly, young people's general societal impotence turns towards a new social power situation within a gang.

The increasingly widespread debate about gang problems, including problems of ethnic minority youth, is related to these challenges. The trajectory concept indicated that there are life paths, an individual may take for coping with life, but also that a person's actions create a trajectory or "career” through life. Perhaps joining a gang represents a central late-modern life course for young people who are not gifted or are not able to succeed in education.

Many features of late-modern welfare society contribute to the challenges for young people. Consumer pressure and "individualisation" in the sense that everyone must ensure their own interests have created a new foundation for the development of the young generation. This again shows that the major requirement to be somebody, to be a successful person, and to show that you have talent also contributes to the fact that young people want a "visible career" such as they find in a gang. And in the gang world, any uncertainty about being successful can be replaced by a social success among friends.

For some young people, there are not many alternative career paths, so they find likely success in the opportunity to become involved in another network, a "societal gang", and in the gang, they develop security and logics and rules for participation, a particular "doxa”, as Bourdieu would call it (Bourdieu, 1980; Jenkins, 1992).

With a perception of crime as business, a possible shift from social gang to societal gang seems therefore quite appealing. Young people find a context which guarantees their self-esteem and their own interests. At the same time, the gang offers a social network with guidelines and institutionalised patterns of interaction. Pay and purchasing power are extremely high and much higher than that would be achieved through education and normal work. Furthermore, the activities are challenging and exciting, they put the individual at the centre, and gang life offers clear "career prospects" and consumer identities.

Only a very small proportion of young people will ever have the chance to take part in youth/young adult life as portrayed in the media, and for those with social disadvantages and without educational qualifications, the future is particularly bleak. This of course also applies to many (most male) young immigrants who find limited job opportunities in their struggle to cope with school and education and the simultaneous experience of marginalisation or exclusion from late-modern society. Many of these immigrant youth groups are therefore subject to the same logic. 
The specific and violent conflict resolution as the typical methods of societal gangs are not in direct opposition to the behaviour young people who may have developed in their everyday lives and in social gangs. A "relative deindividualisation" and a "socialisation" in social gangs influence social conflict behaviour. And especially in the case of ethnic minority, youth have grown up in conflict-ridden areas or refugee camps, their forms of conflict resolution often contrast with traditional local perceptions of what is acceptable.

There are therefore major problems connected to the differentiation emerging today. Past social inequality has now been replaced with individual differentiation and precisely the link between social inequality and individual differentiation is a dangerous cocktail. It is therefore no wonder that especially young people with weak social backgrounds and lack of school success get into difficulties because they cannot easily succeed in social integration. The division of gangs into immigrant gangs and social or societal gangs simply shows that social gangs and networks bring together young people with similar backgrounds, and that when they become societal gangs they will be in competition, which may be viewed and described as gang warfare.

\section{The Challenge}

In seeking a solutional perspective to both the gang issue and general youth challenges, it becomes evident that solutions are not merely a question of individually directed efforts, i.e., "exit programmes". There is a fear that every time we manage to get someone out, there is a new person ready to step in. Exit programs may even create new carrier tracks for others. The gang problem is quite clearly a development brought about by societal and social life, which involves many conflicting interests. Both educators and police can easily feel that they are tilting at windmills.

At an overall level, it is not difficult to point to a substantial solution. We must establish alternative opportunities for success for young people which accept their diversity and which are worth investing in for youth, and the young people should receive support in choosing these options, so more police action will not solve the problem, although it may be necessary when the police have their back against the wall, because the gangs are setting the agenda. If we attempt to view young people, especially social gang members, in a broad activity theoretical perspective, we must clearly operate both on societal, social, and individual levels and create new educational opportunities and social integrative possibilities. Societal opportunities and especially educational contexts are often differentiated; they are different for girls and boys, such as social classes, town and country, and cultural affinity.

Young people's backgrounds baggage is also different. It refers to social, cultural, gender, and even biological differences, but even though the background circumstances are individual, they may be very similar to those of others. In group life, individual backgrounds unite young people. Young people can thus develop a self-understanding or self-identity shaped in social networks with others in a similar situation. The social contexts teach the individual to evaluate himself. The social network works as a catalyst for young people's self-concept.

Therefore, young people's networks are most important, and it becomes important to focus on their social gang network activities. They must be supported in developing their own understandings of self-responsibility as both personal, social, and societal. Making social life and social gangs expedient for social integration seems to be the most important intervention against the development of societal gangs. Here, more knowledge may come from peer education or peer learning initiatives, as they were developed in the 1990s (Mørch \& Laursen, 1998). 


\section{References}

Andersen, H., \& Mørch, S. (2005). Individualisation and the challenged subject. Identity: An International Journal of Theory and Research, 5(3), 261-285.

Arnett, J. J. (2004). Emerging adulthood: The winding road from the late teens through the twenties. New York: Oxford University Press.

Baran, P. A., \& Sweezy, P. (1968). Monopoly capital. London: Penguin Books.

Bauman, Z. (1997). Work, consumerism and the new poor. London: Open University Press.

Bechmann, J. T. (Ed.). (2004). In between generations: The European villager. København: Københavns Universitet.

Beck, U. (1997). The risksociety — On the road to a new modernity. København: Hans Reitzels Forlag.

Bourdieu, P. (1980). The logic of practice. Stanford: Stanford University Press.

Brückner, P. (1972). Zur socialpsychologie des kapitalismus. E.V. Verlagsanstalt, Frankfurt a.M..

Côté, J. E. (2000). Arrested adulthood: The changing nature of maturity and identity. New York: SUNY.

Frønæs, I., \& Brusdal, R. (2000). Tracing a new time. Oslo: Fakbogforlaget.

Furlong, A., \& Cartmel, F. (1997). Young people and social change: Individualisation and risk in late modern society. Buckingham: Open University Press.

Galbraith, J. K. (1967). The new industrial society. København: Gyldendal.

Giddens, A. (1987). The constitution of society. Cambridge: Polity Press.

Giddens, A. (1991). Modernity and self-identity. Cambridge: Polity Press.

Gillis, J. R. (1981). Youth and history. New York: Academic Press

Hobsbawn, E. (1973). Bandits. Harmondsworth: Penguin Books.

Holligan, C. P., \& Deuchar, R. (2009). Territorialities in Scotland: Perception of young people in Glasgow. Journal of Youth Studies, 12(6).

Jenkins, R. (1992). Pierre Bourdieu. London: Routledge.

Klein, M. W. (2001). The European paradox: Street gangs and youth groups in the U.S. and Europe. Dordrecht, The Netherlands: Kluwer Academic Press.

Mørch, S. (1985). Researching youth. København: Rubikon.

Mørch, S. (1995). Young adults: Problems and research perspectives. In Psychological Yearbook (Vol. 2). København: Museum Tusculanum Press.

Mørch, S. (2003). Youth and education. Young, 11(1), 49-73.

Mørch, S. (2010). Youth researh as a perspective and an opportunity. Psyke og Logos, 1, 11-44.

Mørch, S., \& Laursen, S. (1998). Learning to become youth. Odense: Ungdomsringen.

Stafseng, O. (1996). The historical construction of modern youth. Oslo: Kappelen Akademisk Forlag.

Trasher, F. M. (1927). The gang. Chicago: Chicago University Press.

Ziehe, T., \& Stubenrauch, H. (1982). An argument for an uncommon learning. Rohwolt: Reinbek. 